\title{
Altered Gene Expression Pathways in Duchenne Muscular Dystrophy
}

\author{
Nevenka Juretić, Francisco Altamirano, \\ Denisse Valladares and Enrique Jaimovich \\ Centro de Estudios Moleculares de la Célula, Facultad de Medicina, \\ Universidad de Chile, Santiago, \\ Chile
}

\section{Introduction}

Duchenne muscular dystrophy (DMD) is caused by the absence of functional dystrophin (Blake et al. 2002). Dystrophin is a cytoskeleton protein normally expressed in the inner face of the plasma membrane (Ahn and Kunkel 1993). In normal skeletal muscle, dystrophin is associated with a complex of glycoproteins known as dystrophin-associated proteins (DAPs), providing a linkage between the extracellular matrix (ECM) and cytoskeleton (Batchelor and Winder 2006). Lack of dystrophin in dystrophic muscle results in loss of the complex integrity and allegedly impairs the stability of the plasma membrane causing mechanical stress fragility, and an increase in $\mathrm{Ca}^{2+}$ permeability (Alderton and Steinhardt 2000). But the pathophysiology of muscular dystrophy is not only explained by this increased mechanical fragility and a role for dystrophin and DAPs has been suggested as being part of a protein signaling complex involved in cell survival (Rando 2001). In this chapter we discuss evidence of such a role, which may evidence possible interactions between dystrophin and proteins other than those involved in DAP and possible cell location of dystrophin in regions other than the sarcolemma cytoskeleton.

\section{Calcium homeostasis}

$\mathrm{Ca}^{2+}$ is a highly versatile second messenger that can regulate several cellular functions. Skeletal muscles use $\mathrm{Ca}^{2+}$ for contraction process and as regulatory signaling molecule. Subsequently, muscle plasticity is closely related with calcium signals (Berchtold et al. 2000).

Under resting conditions, wild type $(w t)$ skeletal muscle cells maintain the cytosolic calcium concentration $\left(\left[\mathrm{Ca}^{2+}\right]_{\mathrm{i}}\right)$ around 100-120 nM (Lopez et al. 1987; Eltit et al. 2010). Since the chemical gradient between $\left[\mathrm{Ca}^{2+}\right]_{i}$ and extracellular medium or sarcoplasmic reticulum (SR) is about 10,000 fold, to constantly keep the $\left[\mathrm{Ca}^{2+}\right]_{\mathrm{i}}$ in the $\mathrm{nM}$ range, skeletal muscle cells uses a complex machinery to finely regulate calcium concentration. Plasma membrane $\mathrm{Ca}^{2+}$-ATPase (PMCA), $\mathrm{Na}^{+} / \mathrm{Ca}^{2+}$ exchanger (NCX) in the plasma membrane and the SR $\mathrm{Ca}^{2+}$-ATPase (SERCA) extrudes the $\mathrm{Ca}^{2+}$ to extracellular space or to SR, respectively. These functions are opposed, under resting conditions, for the SR $\mathrm{Ca}^{2+}$ leak type-1 ryanodine receptor (RyR1) channels and the basal sarcolemma Ca ${ }^{2+}$ influx (Eltit et al. 2010). 


\subsection{Altered resting calcium in DMD}

Several reports demonstrate that the $\left[\mathrm{Ca}^{2+}\right]_{\mathrm{i}}$ is elevated in $m d x$ mice and DMD human fibers (Lopez et al. 1987; Yeung et al. 2005; Allen et al. 2010). Lopez et al. (1987) have shown that the $\left[\mathrm{Ca}^{2+}\right]_{\mathrm{i}}$ in DMD muscle fibers is $370 \mathrm{nM}$, while in normal muscle fibers was around 100 $\mathrm{nM}$ (Lopez et al. 1987). Similar results were obtained in $m d x$ adult fibers compared with the $w t$ counterpart (Yeung et al. 2005; Allen et al. 2010). The authors demonstrated that $\left[\mathrm{Ca}^{2+}\right]_{\mathrm{i}}$ was elevated under resting conditions in $m d x$ fibers and when the fibers were exposed to stretch-induced damage, $\left[\mathrm{Ca}^{2+}\right]_{\mathrm{i}}$ increased to higher levels, around $700 \mathrm{nM}$ (Yeung et al. 2005; Allen et al. 2010).

Increased $\left[\mathrm{Ca}^{2+}\right]_{i}$ has been related with necrosis through calpain activation and mitochondrial permeability transition pore (MPTP) (Turner et al. 1988; Spencer et al. 1995; Millay et al. 2008).

The mechanism that has been proposed for dystrophin function involves a role in sarcolemma stabilization, so in muscle fibers that lack this protein, membrane damage would be recurrent (Petrof et al. 1993; Mokri and Engel 1998). These evidences suggested the hypothesis of $\mathrm{Ca}^{2+}$ leak into the cell through damaged membrane. There are several evidences in $m d x$ muscle fibers that relate the calcium entry with the transient receptor potential channels (TRPC1) and the store-operated calcium entry (SOCE) mechanism. TRPC1-dependent calcium entry is increased in $m d x$ muscle fibers (Vandebrouck et al. 2002; Yeung et al. 2005; Gervasio et al. 2008). The blockage of these cationic channels with streptomycin or spider venom toxin (GsMTx4) reduced $\left[\mathrm{Ca}^{2+}\right]_{i}$ and prevented the rise of the $\left[\mathrm{Ca}^{2+}\right]_{i}$ following stretch (eccentric) contractions. This maneuver, partially reduced the decline in both the tetanic $\mathrm{Ca}^{2+}$ increase and force (Yeung et al. 2005; Allen et al. 2010). Gervasio et al. 2008 showed that TRPC1, caveolin-3 and Src-kinase protein levels are increased in $m d x$ muscle (Gervasio et al. 2008). The authors propose that the stretch-induced muscle damage and the increase in the $\left[\mathrm{Ca}^{2+}\right]_{\mathrm{i}}$ is produced by the ROS production, activation of Src-kinase and TRPC-induced $\mathrm{Ca}^{2+}$ entry. Furthermore, administration of streptomycin reduced muscle damage and increased myofiber regeneration (Yeung et al. 2005).

More recently, store-operated calcium entry has been implicated in the exacerbated resting $\mathrm{Ca}^{2+}$ entry observed in $m d x$ fibers (Boittin et al. 2006; Vandebrouck et al. 2006; Edwards et al. 2010). These $\mathrm{Ca}^{2+}$ entries are modulated by a $\mathrm{Ca}^{2+}$-independent phospholipase $\mathrm{A}_{2}$, which is overexpressed in dystrophic fibers (Boittin et al. 2006). Vandebrouck et al. (2005) demonstrate that the high store-operated $\mathrm{Ca}^{2+}$ transients observed in dystrophin-deficient myotubes were associated with sustained cytosolic $\mathrm{Ca}^{2+}$ transients and high intramitochondrial entries, that can be reduced by mini-dystrophin expression or FCCP (uncoupler of oxidative phosphorylation) (Vandebrouck et al. 2006). In addition, the thresholds for SOCE activation and deactivation occur at higher $\left[\mathrm{Ca}^{2+}\right]_{S R}$ and the proteins levels of STIM1 and Orai1 was 3-fold increased in extensor digitorum longus (EDL) muscles from $m d x$ mice (Edwards et al. 2010).

\subsection{SR Ca ${ }^{2+}$ loading capacity}

There is a controversy about the loading capacity of the SR $\left[\mathrm{Ca}^{2+}\right]_{\mathrm{SR}}$ in dystrophic skeletal muscle cells compared with normal skeletal muscle cells. Roberts et al. (2001), using a $\mathrm{Ca}^{2+}$ sensitive photoprotein aequorin chimera with SR destination sequence, show that after SR 
$\mathrm{Ca}^{2+}$ depletion, the re-addition of $\mathrm{Ca}^{2+}$ to the media increases the $\left[\mathrm{Ca}^{2+}\right]_{\mathrm{SR}}$ rapidly up to a steady state that is $50 \%$ higher that the $w t$ myotubes (Robert et al. 2001). In contrast, Culligan et al. (2002) shows a reduction in $\mathrm{Ca}^{2+}$ binding in the SR microsomes from $m d x$ mice, associated with a drastic reduction in the calsequestrin-like proteins and normal SERCA1 expression and activity (Culligan et al. 2002). However, a reduction in SERCA activity has been observed in dystrophic muscle (Kargacin and Kargacin 1996; Divet et al. 2005), which could account for the increased $\left[\mathrm{Ca}^{2+}\right]_{\mathrm{i}}$. SERCA1a overexpression in $m d x$ diaphragm muscle by adeno-associated virus gene transfer, resulted in a reduction of centrally located nuclei and reduced susceptibility to eccentric contraction-induced damage (Morine et al. 2010). More recently, $\delta$-sarcoglycan-null and $m d x$ mice transgenic animals that overexpress SERCA1, show a reduction in myofiber central nucleation, tissue fibrosis and serum creatine kinase levels. In addition SERCA1 overexpression enhances excitationcontraction (E-C) coupling and restore the $\left[\mathrm{Ca}^{2+}\right]_{\mathrm{i}}$ and $\left[\mathrm{Ca}^{2+}\right]_{S R}$ in both dystrophic models (Goonasekera et al. 2011).

\subsection{Excitation-Contraction (E-C) coupling}

The proteins involved in E-C coupling are normally expressed in dystrophic muscle. The expression of $\alpha 1-, \alpha 2$ - and $\beta$-subunits of the dihydropyridine receptor (DHPR) are similar in microsomes from control and $m d x$ mice (Culligan et al. 2002). RyR1 and SERCA1 are also found in comparable amounts in control and dystrophin-deficient muscles (Culligan et al. 2002).

In skeletal muscle cells, membrane depolarization induces a conformational change in Cav1.1 DHPRs that is transmitted to the ryanodine receptor (RyR1), causing it to release $\mathrm{Ca}^{2+}$ from the SR, that it is necessary for the contraction process.

Several evidences indicate that the dystrophic skeletal muscle cells have an unpaired E-C coupling. Comparisons of the cytosolic calcium transients evoked by single action potential have shown that the calcium transients are reduced in $m d x$ fibers compared with wt fibers (Woods et al. 2004; Hollingworth et al. 2008). Recently, similar results have been found in fibers from $u t r-/-m d x$ mice (Capote et al. 2010). Muscle weakness observed in isolated fibers from $m d x$ mice and DMD patients has not been fully explained. The reduction in the $\mathrm{Ca}^{2+}$ transient evoked by single action potential, reduction in $\left[\mathrm{Ca}^{2+}\right]_{\mathrm{SR}}$ and increased $\left[\mathrm{Ca}^{2+}\right]_{\mathrm{i}}$ could provide a mechanism for contractile dysfunction and impaired force production in DMD patients.

\section{Excitation-Transcription (E-T) coupling}

We have previously described that membrane depolarization of skeletal myotubes evokes a fast $\mathrm{Ca}^{2+}$ transient during the stimuli, that promotes a contractile response through " $\mathrm{E}-\mathrm{C}$ coupling", and a slow $\mathrm{Ca}^{2+}$ transient peaking 60-100 seconds later, mostly associated to cell nuclei (Jaimovich et al. 2000; Estrada et al. 2001; Powell et al. 2001; Araya et al. 2003; Cardenas et al. 2005). Slow $\mathrm{Ca}^{2+}$ transients are involved in the "E-T coupling" mechanism, which relates membrane depolarization with gene expression (Powell et al. 2001; Araya et al. 2003; Carrasco et al. 2003; Juretic et al. 2006; Juretic et al. 2007). The signaling pathway begins at the DHPR, which by a mechanism involving G protein (Eltit et al. 2006), activates 
PI3 kinase and PLC to produce inositol 1,4,5-trisphosphate $\left(\mathrm{IP}_{3}\right)$ that diffuses in the cytosol and reaches $\mathrm{IP}_{3}$ receptors $\left(\mathrm{IP}_{3} \mathrm{Rs}\right)$ located both at the SR membrane and at the nuclear envelope, promoting $\mathrm{Ca}^{2+}$ release (Araya et al. 2003). $\mathrm{IP}_{3}$ mediated $\mathrm{Ca}^{2+}$ signals induce both a transient activation of ERK $1 / 2$ and transcription factor CREB, and an increase in early genes (c-fos, c-jun and egr-1) and in late genes (troponin I, interleukin-6, hmox and hsp70) mRNA levels after depolarization of normal skeletal muscle cells (Carrasco et al. 2003; Juretic et al. 2006; Juretic et al. 2007; Jorquera et al. 2009). Moreover, in electrically stimulated adult muscle fibers, slow $\mathrm{Ca}^{2+}$ signals mediate the frequency-dependent activation of slowphenotype muscle fiber genes (slow troponin I, TnIs) and repression of fast-phenotype ones (TnIf) (Casas et al. 2010). These evidences link slow $\mathrm{Ca}^{2+}$ transients with muscular effects of nerve activity and with the process of muscle cell plasticity.

Recently we described a new role for ATP signaling in skeletal muscle in a process called "E-T" coupling (Buvinic et al. 2009, see Fig.1). We were able to show that the main ATP efflux pathway is through pannexin 1 hemichannels. We know that DHPR receptors and pannexin 1 interact with each other but it is not clear whether it is a direct interaction. The ATP released will locally activate the purinergic receptors P2X and P2Y localized in the membrane. This activation induces a transient increase in intracellular $\mathrm{Ca}^{2+}$ with specific kinetics. We demonstrated that ATP participates in the fast calcium transient related to contraction because apyrase (catalyses the hydrolysis of ATP) reduced the depolarizationevoked $\mathrm{Ca}^{2+}$ transient by about $20 \%$. We can speculate that activation of P2X receptors may contribute to improve the skeletal muscle cells $\mathrm{Ca}^{2+}$ availability needed to sustain contractions. Moreover, we could also show that ATP participates in "E-T" coupling due to the total inhibition by apyrase of the second $\mathrm{Ca}^{2+}$ transient induced by depolarization. Additionally, the use of apyrase during the electrical stimulation completely abolished the increase in gene expression related with muscle plasticity (unpublished data). We can conclude that gene expression is regulated through activation of P2Y receptors mediated by the ATP released during depolarization.

\subsection{Extracellular ATP: a major mediator for signal transduction}

ATP for a long time was considering as a molecule that was involved with energy and metabolism of many cells. Nevertheless in the last few years ATP has been considered as an extracellular messenger for autocrine and paracrine signaling (Corriden and Insel 2010). It has been described as a regulator of inflammation, in embryonic and stem cell development, ischemia, among others (Bours et al. 2006; Burnstock and Ulrich 2011). In skeletal muscle ATP has been implicated in the regulation of proliferation, differentiation and regeneration (Ryten et al. 2002; Ryten et al. 2004) and also promoting the stabilization of the neuromuscular junction (Jia et al. 2007).

ATP release is induced in response to several kinds of stress in many cells type, including hypoxia, ischemia, osmotic swelling and mechanical stimulation (Corriden and Insel 2010). ATP can exit cells using several different purinergic signal efflux pathways (Fitz 2007). The main source of extracellular ATP is cell lysis, which occurs when massive cell death takes place during trauma, injury or inflammation. A non-lytic source of ATP is the release of secretory granules during stimulated exocytosis, which occurs in secretory cell types like epithelial cells of the liver, lung, kidney, neurons and astrocytes (Volonte and D'Ambrosi 
2009). A non-lytic, and also non-exocytotic release of ATP can occur by channel- or transporter-mediated mechanisms, such as: (a) hemichannels, such as connexins and pannexin (Dubyak 2009); (b) anion channels, such as plasmalemma voltage dependent anion channel, voltage-dependent maxi-anion channel, volume sensitive $\mathrm{Cl}^{-}$channel and $\mathrm{P} 2 \mathrm{X} 7$ receptor (Sabirov and Okada 2005; Suadicani et al. 2006; Liu et al. 2008); (c) ATP-binding cassette transporters, such as cystic fibrosis transmembrane conductance regulator $\mathrm{Cl}^{-}$ channel and P-glycoprotein (Campbell et al. 2003; Sabirov and Okada 2005); and (d) exchange carriers such as ADP/ATP exchange carrier (Sabirov and Okada 2005; Volonte and D'Ambrosi 2009). Several studies have recently demonstrated that ATP can be released by pannexin hemichannels in a variety of cells types that include myotubes (D'Hondt et al. 2011). Pannexin is widely distributed among tissues with cell communication via calcium waves (Shestopalov and Panchin 2008). The channel formed by this protein can be opened by mechanical perturbation at the resting membrane potential. The channel is permeable for ATP and it can be opened at physiological calcium concentration (Barbe et al. 2006). These properties make pannexin 1 (Panx1) a very attractive candidate for an ATP-releasing channel. The widespread distribution of Panx1 has been confirmed in a variety of human tissues, with the highest levels being found in skeletal muscle (Baranova et al. 2004). Results of our laboratory indicate that this hemichannel is expressed in myotubes and adult fibers of rat and mouse.

Once released, ATP acts as an extracellular signal trough the binding to purinergic receptors expressed in most cell types. Purinergic receptors comprise both ionotropic P2X receptor subtypes and G-protein-coupled P2Y receptor subtypes (Burnstock 2004). Between the purinergic receptors and the purine-generating reactions, there exist purino-converting enzymes. These enzymes named ectonucleotidases, consist of several different families with well-characterized molecular and functional features (Yegutkin 2008). They operate to metabolize nucleotides down to the respective nucleoside analogues, thus having the potential to decrease the extracellular concentrations of nucleotides. Consequently these enzymes modulate ligand availability at both nucleotide and nucleoside receptors (Yegutkin 2008). The contribution of the diverse ectonucleotidases to the modulation of purinergic signaling depends on their availability of different ectonucleotidases and their selectivity for substrates, but also on their abundance and cell distribution (Volonte and D'Ambrosi 2009).

ATP signaling has been implicated in many cell functions ranging from proliferation, differentiation, toxic actions, neurotransmission, smooth and cardiac muscle contraction, vasodilation, chemosensory signaling and secretion, to complex phenomena such as immune responses, male reproduction, fertilization, embryonic development, and so on (Burnstock 2004). This vast heterogeneity of their biological responses is influenced by different parameters such as the presence of endogenous ligands at receptor sites and the time and distance from the source of release; the concentration gradient of a ligand that simultaneously can activate more than one receptor subtype; the different composition of purinergic receptors in a given cell, or even more the composition in the diverse sub membrane compartments in which each ligand operates (Volonte and D'Ambrosi 2009).

\subsection{Purinergic receptors}

Purinergic receptors are subdivided into two major groups: eight G-protein-coupled seventransmembrane P2Y subunits (P2Y1, 2, 4, 6, 11-14), and seven P2X ligand-gated ion channels 
$\left(\mathrm{P} 2 \mathrm{X}_{1-7}\right)$. These two types of receptor have larger differences in their aminoacid sequences, molecular/physiological properties and relative sensitivities to ATP, with ranges of nanomolar for P2Y, low micromolar for most P2X, to high micromolar for P2X7. Moreover the complexity of these receptors is augmented because both subtypes can form homomers and heteromers and these different combinations can change the agonist and antagonist selectivity, transmission signaling, channel and desensitization properties (Nakata et al. 2004).

P2X receptors are ATP-gated ion channels that mediate sodium influx, potassium efflux and, to varying extents, calcium influx, leading to depolarization of the cell membrane. Membrane depolarization subsequently activates voltage-gated calcium channels, thus causing accumulation of calcium ions in the cytoplasm. The predicted structure of the P2X subunits is a transmembrane protein with two membrane spanning domains that are involved in gating the ion channel and lining the ion pore (Surprenant and North 2009). Functional P2X receptor ion channels are now thought to consist of three subunits that could be homomers and heteromers (North 2002). The different combinations present different desensitization and permeability properties, as well as agonist and antagonist specificities. $\mathrm{P} 2 \mathrm{X}$ receptors are widely distributed, and in neurons, glial cells, bone, muscle, endothelium, epithelium, and hematopoietic cells, they have functional roles. Moreover, several studies have implicated these receptors in the pathophysiology of Parkinson's disease, Alzheimer's disease, and multiple sclerosis (Jarvis and Khakh 2009).

P2Y receptors are G-protein-coupled receptors (GPCRs) that are activated by purine and/or pyrimidine nucleotides. Like other members of the GPCR superfamily, they are composed of seven transmembrane spanning regions that assist in forming the ligand binding pocket and also the purinergic receptor (Abbracchio et al. 2006). Stimulation leads to activation of heterotrimeric $G$ proteins and their dissociation into $\alpha$ and $\beta \gamma$ subunits that can then interact with a variety of effector proteins. Some of P2Y receptors are activated mainly by nucleoside diphosphates $\left(\mathrm{P} 2 \mathrm{Y}_{1,6,12}\right)$, while others are activated mainly by nucleoside triphosphates $\left(\mathrm{P} 2 \mathrm{Y}_{2,4}\right)$. Otherwise, some P2Y receptors are activated by both purine and pyrimidine nucleotides (P2 $\left.\mathrm{Y}_{2,4,6}\right)$, and others only by purine nucleotides (P2 $\left.\mathrm{Y}_{1}, 11,12\right)$ (Jacobson et al. 2009). Each individual P2Y receptor subtypes can couple to distinct $G$ proteins that are specific for each cell type or tissue. The abilities to activate different $G$ proteins were inferred from their capability to induce increases in inositol tris-phosphate, cytoplasmic $\mathrm{Ca}^{2+}$, or cyclic AMP levels, and determination of sensitivity to the Gi/o protein inhibitors pertussis toxin (PTX) (Abbracchio et al. 2006). P2Y receptors can also be coupled to the activation of monomeric $G$ proteins like Rac and RhoA. Even more, in the last few years many studies have revealed that a cross-talk exist between different GPCRs and their downstream effectors as well as between GPCRs and other signaling proteins, such as ion channels, integrins, and receptor and non-receptor tyrosine kinases (von Kugelgen 2006). These properties explain how the activation of particular P2Y receptors can lead to the induction of more than one signaling pathway in the same cell type. These receptors are able to regulate many different functions in a variety of cell types, and for that reason an intense effort has been developed to design selective agonist and antagonist ligands, both as pharmacological tools and as potential therapeutic agents (Abbracchio et al. 2003; Brunschweiger and Muller 2006). For cystic fibrosis, dry eye disease, and thrombosis the application of $\mathrm{P} 2 \mathrm{Y}$ receptor ligands has been tested as drug candidates. The development of 
new chemical compounds will provide new opportunities for therapeutics of several diseases, including cardiovascular diseases, inflammatory diseases, and neurodegeneration (Jacobson and Boeynaems 2010).

Between the many functions that P2 receptors can regulate is ion channel activity. The studies have been performed mainly in neurons, in which specific P2 subtype can regulate the N-type $\mathrm{Ca}^{2+}$ channel and the $\mathrm{M}$-current $\mathrm{K}^{+}$channel. Nevertheless, recent studies have demonstrated that P2 receptors can induce fast inhibitory junction potential in rat colon (Grasa et al. 2009), membrane hyperpolarization in vascular endothelial cells (Raqeeb et al. 2011), $\mathrm{Ca}^{2+}$ influx mediated contraction in intestinal myofibroblasts (Nakamura et al. 2011), and contraction induced by electrical field stimulation in smooth muscle (Cho et al. 2010). These data suggest that ATP signaling is important in excitable cells for their normal function. In skeletal muscle there are many evidences of the importance of ATP signaling. The activation of $\mathrm{P} 2$ receptors has been associated with modulation of $\mathrm{Ca}^{2+}$ influx and signaling (Sandona et al. 2005; May et al. 2006), activation of the ERK $1 \frac{1}{2}$ (May et al. 2006), muscle contractility (Sandona et al. 2005; Grishin et al. 2006), and regulation of excitability of muscle fibers (Voss 2009; Broch-Lips et al. 2010). Also extracellular nucleotides play important functions during skeletal muscle development and regeneration (Ryten et al. 2002; Ryten et al. 2004). Importantly, it has been shown that ATP promotes differentiation of rat skeletal muscle satellite cells (Araya et al. 2004; Banachewicz et al. 2005).

\section{Alterations in both $\mathrm{IP}_{3} R$ s and E-T coupling in DMD models}

We have described that the amount of $\mathrm{IP}_{3} \mathrm{Rs}$, as well as the total mass of $\mathrm{IP}_{3}$, are largely increased in both an $m d x$ mice derived cell line and in a human DMD derived cell line compared to normal cells (Liberona et al. 1998). In dystrophic skeletal muscle, it has been suggested that an alteration of $\mathrm{Ca}^{2+}$ homeostasis occurs and might be responsible for muscle degeneration (Turner et al. 1988; Turner et al. 1991). Several studies indicate that $\mathrm{IP}_{3}$ pathways could be involved in the DMD pathophysiology (Liberona et al. 1998; Balghi et al. 2006a; Balghi et al. 2006b). We recently found that both expression and localization of $\mathrm{IP}_{3} \mathrm{Rs}$ are different in normal and dystrophic human skeletal muscle and cell lines (Cárdenas et al. 2010). On the other hand, experiments performed using two types of myotubes originated from the same Sol8 cell line - dystrophin deficient myotubes, SolC1(-), and myotubes transfected to express the minidystrophin, $\mathrm{SolD}(+)$ - show that $\mathrm{Ca}^{2+}$ rise evoked by potassium depolarization was higher in SolC1(-) than in $\operatorname{SolD}(+)$ myotubes (Balghi et al. 2006a). Analysis of the kinetics of the $\mathrm{Ca}^{2+}$ rise, reveals that the slow $\mathrm{IP}_{3}$-dependent release may be increased in the SolC1(-) as compared to the SolD(+), suggesting an inhibitory effect of mini-dystrophin on $\mathrm{IP}_{3} \mathrm{R}$-dependent $\mathrm{K}^{+}$-evoked $\mathrm{Ca}^{2+}$ release (Balghi et al. 2006a). Moreover, it has been described that $\mathrm{IP}_{3}$ production after membrane depolarization is significantly elevated in dystrophin-deficient myotubes and that the presence of minidystrophin under the membrane leads to reduced $\mathrm{IP}_{3}$ production (Balghi et al. 2006a). In fact, we have recently demonstrated, using normal (RCMH) and dystrophic (RCDMD) human skeletal muscle cell lines, that $\mathrm{IP}_{3}$ dependent, slow $\mathrm{Ca}^{2+}$ transients evoked by electrical stimulation are faster in dystrophic cells, compared to normal myotubes (Cárdenas et al. 2010). Electrical stimulation induced an important phosphorylation of $\mathrm{ERK}^{1} \frac{1}{2}$ in normal but not in dystrophic cells, and a differential pattern of gene expression between cell lines. 
In normal adult mice skeletal muscle, we observed that $\mathrm{IP}_{3} \mathrm{R}$ immuno-labeling follows distinctive patters resembling the SR (types 1, 2 and $3 \mathrm{IP}_{3} \mathrm{Rs}$ ), sarcolemmal (types 1 and 3 $\mathrm{IP}_{3} \mathrm{Rs}$ ) or nuclear localizations (types 1 and $3 \mathrm{IP}_{3} \mathrm{Rs}$ ) (Casas et al. 2010). The labeling for both type 1 and type $2 \mathrm{IP}_{3}$ Rs subtypes showed a fiber type-specific distribution with much higher expression in fast (type II) muscle fibers, whereas type $3 \mathrm{IP}_{3} \mathrm{R}$ showed a uniform distribution in both fiber types, as shown by co-labeling with slow myosin heavy chain antibody. Likewise, mice muscle fibers show a characteristic mosaic pattern for type $1 \mathrm{IP}_{3} \mathrm{R}$ (Casas et al. 2010). When human muscle was studied, type II muscle fibers showed a much more intense labeling for the $\mathrm{IP}_{3} \mathrm{R}$ subtype 1 compared to type I (slow) fibers. In biopsies from DMD patients, we found that $24 \pm 7 \%$ of type II fibers have totally lost type $1 \mathrm{IP}_{3} \mathrm{R}$ labeling, compared to age-matched control biopsies (Cárdenas et al. 2010). On the other hand, RCDMD cells show a five-fold over expression of type $2 \mathrm{IP}_{3} \mathrm{Rs}$ and down regulation of type $3 \mathrm{IP}_{3}$ Rs compared to normal RCMH cells (Cárdenas et al. 2010). Unlike normal muscle cells, type $2 \mathrm{IP}_{3} \mathrm{R}$ locate in the nucleus in RCDMD cells, while type 1 and type $3 \mathrm{IP}_{3} \mathrm{Rs}$ also display a particular subcellular location for each line (Cárdenas et al. 2010). These results showed that $\mathrm{IP}_{3} \mathrm{Rs}$ expression and localization are different in muscle affected by DMD.

\section{Signaling by extracellular nucleotides in dystrophic skeletal muscle}

A number of skeletal muscle pathologies have been associated with alterations in the metabolism of extracellular ATP, changes in the sensitivity towards ATP and altered expression of purinergic receptors; among these pathologies we have DMD. In recent works, ATP signaling has been implicated in abnormal calcium homeostasis in dystrophic muscle and proposed to have implications in the pathogenesis of muscular dystrophies. Moreover, in myoblasts of a dystrophin negative muscle cell line, exposure to extracellular ATP elicited a strong increase in cytoplasmic $\mathrm{Ca}^{2+}$ concentrations. This increased susceptibility to ATP was due to changes in expression and function of P2X receptors and proposed to be a significant contributor to pathogenic $\mathrm{Ca}^{2+}$ entry in dystrophic mouse muscle (Yeung et al. 2006). The plasma membrane $\mathrm{Na}^{+} / \mathrm{H}^{+}$exchanger (NHE) has been proposed to be involved in the pathogenesis of muscular dystrophy, most probably through the sustained increase in intracellular $\mathrm{Ca}^{2+}$. The mechanism by which NHE is constitutive activated appears to be through stimulation of P2 receptors with ATP being continuously released in response to stretching (Iwata et al. 2007).

Nevertheless, these works failed to explain the mechanism by which ATP is released from skeletal muscle. ATP in skeletal muscle was proposed to be co-released with acetylcholine from motor nerve terminals during nerve activation (Smith 1991; Silinsky and Redman 1996) and released from muscle fibers during contraction (Cunha and Sebastiao 1993; Hellsten et al. 1998). Dystrophic muscle would be expected to contain high levels of extracellular ATP due mainly to fiber injury.

We propose now that in skeletal muscle, ATP is released upon contraction or electrical stimulation mainly through activation of pannexin 1 hemichannels. Any disturbance in either pannexin 1 channels or changes in P2 receptors expression or activity will have implications in skeletal muscle normal function. The possibility that this system is altered in muscular dystrophies raises new possibilities of therapeutic strategies in the treatment of diseases like DMD. 
In addition to the structural role for dystrophin and its known associated proteins, there is clear evidence for signal transduction roles. The best studied signaling protein linked is the nNOS pathway. In DMD nNOS appears to be either drastically reduced or even absent (Niebroj-Dobosz and Hausmanowa-Petrusewicz 2005). It has been propose that part of muscle degeneration in DMD may result from the reduction in the production of nNOS/NO (Niebrój-Dobosz, 2005). Lately many additional signaling pathways have been demonstrated to be altered in dystrophy, such as: nuclear factor kappa-B (NF-kB), tumor necrosis factor (TNF)-alpha and interleukin (IL)-6 (Messina et al. 2011). The precise role of these signaling pathways remains mysterious, it is interesting to investigate whether the abnormal regulation of one (or more) of these pathways contributes to skeletal muscle pathogenesis in dystrophy.

To address the different pathways that could be altered in muscular dystrophy, many studies have compared gene expression profile between normal and dystrophic muscle based on microarray analysis. These analysis have been done in patients with DMD and in $m d x$ mice. These studies include different types of muscle and in different times of the human disease (Chen et al. 2000) or in different life periods of $m d x$ mice (Porter et al. 2003b; Lang et al. 2004; Porter et al. 2004; Dogra et al. 2008). In DMD patients biopsies that were individually analyzed, the upregulated genes are related with ECM and cytoskeleton, muscle structure and regeneration, immune response, signal transduction and cell-cell communication (Chen et al. 2000). In the mouse model there are many gene expression studies. The main muscles studied are diaphragm, extraocular muscles and leg muscle groups (Porter et al. 2003b; Lang et al. 2004; Dogra et al. 2008). Among the results, it is worth mentioning that the response to the lack of dystrophin varies in different muscle groups of human and $m d x$ mice, and it was proposed that changes in gene expression could be related with the progression of the disease (Porter et al. 2003b; Lang et al. 2004; Porter et al. 2004; Dogra et al. 2008). Moreover, some groups studied the profile of gene expression in skeletal muscle implicated in specific pathways such as regeneration (Turk et al. 2005), inflammation (Evans et al. 2009a), immune system (Evans et al. 2009b) and specific transcription factors (Dogra et al. 2008). Also there are some studies that propose that expression of utrophin in the $m d x$ mouse muscle results in a gene expression profile that is similar to that seen for the wt mouse (Baban and Davies 2008).

The analysis performed by Porter et al. (2002) established that numerous pathogenic pathways in $m d x$ skeletal muscles are closely related and share features with DMD (Porter et al. 2002). Among the genes that were increased in $m d x$ muscle is purinergic receptor P2X. The $\mathrm{P}_{2} \mathrm{X}_{4}$ up regulation in dystrophic muscle has been attributed to vascular permeability changes and to inflammatory responses (Porter et al. 2002). Later, Yeung et al. (2004) demonstrated that P2X4 were expressed in infiltrating macrophages in dystrophic human and mouse muscle, and could be related with the inflammatory process (Yeung et al. 2004). Jiang et al. 2005 demonstrated that there is a differential expression of P2X receptors that change during the progression of the disease in both human and mouse dystrophic muscle (Jiang et al. 2005). They found that the $P 2 X_{1}$ and $P 2 X_{6}$ receptors are expressed during the process of regeneration in mouse muscular dystrophy, and the expression of $\mathrm{P}_{2} \mathrm{X}_{2}$ is associated with type 1 fibers. Nevertheless, the work of Yeung et al. (2006) demonstrated that increase in P2X receptors increased the susceptibility of dystrophic myoblasts to extracellular ATP (Yeung et al. 2006). They proposed that changes in P2X will significant contribute to pathogenic $\mathrm{Ca}^{2+}$ entry. 
Moreover, studies of Ryten et al. $(2002,2004)$ identified a role for ATP in the regulation of skeletal muscle formation, through inhibiting the proliferation and increase the rate of differentiation of satellite cells (Ryten et al. 2002; Ryten et al. 2004) Later, they show that the $\mathrm{P}_{2} \mathrm{X}_{2}, \mathrm{P}_{2} \mathrm{X}_{5}$ and $\mathrm{P}_{2} \mathrm{Y}_{1}$ receptors were strongly expressed in $m d x$ skeletal muscle and in the cells known to be important for muscle regeneration.

As previously described, P2 receptors have been implicated in the alteration on intracellular calcium. This could also be releated with some of the signaling pathways that are dependent on calcium homeostasis, like the activation of proteases. It has been demonstrated that changes in intracellular calcium can activate calpain and proteolytic damage to sarcomer proteins, like titin (Goll et al. 2003; Zhang et al. 2008).

The original sarcoglycan (SG) complex has four subunits and comprises a subcomplex of the dystrophin-associated protein complex (Hack et al. 2000). Gene defects in $\alpha$-sarcoglycan also lead to a severe muscular dystrophy, type 2D limb-girdle muscular dystrophy (Roberds et al. 1994). The role of sarcoglycans in dystrophin complex function is not entirely understood. The $\alpha$-sarcoglycan was described as an ecto-ATPase with distinctive enzymatic properties in vitro (Betto et al. 1999). Later on, $\alpha$-sarcoglycan was demonstrated to significantly contribute to total ecto-nucleotidase activity of $\mathrm{C} 2 \mathrm{C} 12$ myotubes and during the differentiation of this cell type (Sandona et al. 2004). As a result, mutations of the $\alpha$ sarcoglycan gene causing the loss of its enzymatic function could represent an important mechanism to explain the pathogenesis mechanisms leading to dystrophy.

Taken these studies together, we can conclude that modifications in ATP signaling, due to changes in ATP release mechanism or receptors expression and availability, could be implicated in several mechanisms potentially involved in diseases. For these reasons ATP signaling has been considered as a good candidate for therapeutic targets for the treatment of muscle diseases

\section{Gene expression in DMD}

Microarrays analysis has been the basis of a number of publications in which dystrophic muscle is compared with unaffected muscle. Gene expression comparison of human biopsies from DMD and normal skeletal muscle has shown that many of the differentially expressed genes reflect in histo-pathology changes. For example, immune response signals and ECM genes are overexpressed in DMD muscle, an indication of the infiltration of inflammatory cells and connective tissue (Haslett et al. 2002). cDNA analysis of individual DMD patients have shown that genes related to immune response, sarcomere, ECM and signaling/cell growth were increased. Up-regulation of these genes accompanies dystrophic changes in DMD muscles such as myofiber necrosis, inflammation and muscle regeneration (Noguchi et al. 2003). Up-regulated inflammatory gene expression and activated immune cells are present in dystrophic muscle and play a critical role in muscle wasting (Evans et al. 2009b). The pro-inflammatory cytokines TNF-alpha, IL-1beta and IL-6 are up-regulated in Duchenne patients and $m d x$ mice (Porreca et al. 1999; Porter et al. 2002; Kumar and Boriek 2003; Acharyya et al. 2007; Hnia et al. 2008). The fact that a number of chemokines are expressed directly by the muscle cell suggests that muscle tissue may contribute to chemotaxis process (Porter et al. 2003a). Using microarray technology we have shown that membrane depolarization induces expression and repression of a number of genes in both 
normal (RCMH) and DMD (RCDMD) human skeletal muscle cell lines. Importantly, modulated genes are mostly different for these two cell lines (Cárdenas et al. 2010). Nevertheless, the expression of only 44 of them is modified in both cell lines. The pattern of expression (up- or down-regulation) of these common genes is strikingly different between cell lines, and they appear to be regulated in opposite ways (Cárdenas et al. 2010).

Within these 44 genes we identified genes related to the immune response (HLA-DQB1), cytoskeleton/ECM proteins (ADD1, KRT1, and FBLN1), and signaling (NRG and POU2F2), among others. We found that 18 of these 44 genes are related to processes associated with $\mathrm{Ca}^{2+}$, and 10 of them have been related in some way to dystrophy (Cárdenas et al. 2010).

Within the genes whose expression increases in RCDMD cells, particularly interesting in relation to muscle function and development, are those coding for the two isoforms of neuregulin (NGR1- $\beta 2$ and NRG1- $\gamma$ ) and the POU2F2 gene (Cárdenas et al. 2010). NRG1 is a growth factor that potentiates myogenesis and may play an important role in differentiation of satellite cells in muscle regeneration (Hirata et al. 2007). Moreover, NRG stimulates $\mathrm{Ca}^{2+}$ induced glucose transport during contraction (Canto et al. 2006) and is implicated in the metabolic and proliferative response of muscle to exercise (Lebrasseur et al. 2003). POU2F2 has been described as a transcription factor expressed in developing mouse skeletal muscle (Dominov and Miller 1996).

In addition, we found variations in the expression of ICEBERG, HLA-DQB1, ADD1, FBLN1 and TRIO genes that also have been associated with $\mathrm{Ca}^{2+}$ and dystrophy (Cárdenas et al. 2010). Considering that changes observed in DMD muscle biopsies have been related to elevation of intracellular $\mathrm{Ca}^{2+}$ concentration, which could activate $\mathrm{Ca}^{2+}$-dependent degradation pathways, resulting in myofibril disruption and muscle necrosis (Turner et al. 1993). It will be interesting to analyze the roles described for the above mentioned genes. To our knowledge, there are no studies describing the role of membrane depolarization on the expression of these genes, and further studies are needed to explore the involvement of $\mathrm{IP}_{3^{-}}$ mediated slow $\mathrm{Ca}^{2+}$ signals in the expression of some of these particular genes in skeletal muscle cells (Cárdenas et al. 2010).

Gene expression profiling at different stages in $m d x$ models have also evidenced the highly dynamic process of the disease onset. These works, show that dystrophy in $m d x$ models have an onset at 3 weeks of age, with a peak in pathology around 8 weeks. Interestingly, at this stage, there is a marked upregulation of almost 9 fold of the purinergic receptor $\mathrm{P}_{2} \mathrm{X}_{4}$ (Porter et al. 2003b).

Although no therapy described to date can effectively slow or halt muscle degeneration in dystrophic patients (Kapsa et al. 2003), a promising pharmacological treatment for DMD aims to increase levels of utrophin and to identify molecules that modulate utrophin expression (regulatory pathways) by activation of its promoter (Dennis et al. 1996), in muscle fibers of affected patients to compensate for the absence of dystrophin (Miura and Jasmin 2006).

Indeed, utrophin is considered the autosomal homolog of dystrophin because it shares structural and functional motifs throughout the length of the molecule (Love et al. 1989; Khurana et al. 1990; Nguyen et al. 1991; Ohlendieck et al. 1991; Tinsley et al. 1992). It is capable of associating with members of the DAPs with similar affinity to dystrophin as well (Matsumura et al. 1992; Winder et al. 1995). Studies in the dystrophin-deficient $m d x$ mice have established that the elevation of utrophin levels in dystrophic muscle fibers can restore 
sarcolemmal expression of DAPs members and alleviate the dystrophic pathology (Miura and Jasmin 2006). Direct evidence for the ability of utrophin to functionally substitute for dystrophin comes from experiments demonstrating that transgene-driven utrophin overexpression can effectively rescue dystrophin-deficient muscle in $m d x$ mice (Tinsley et al. 1996; Deconinck et al. 1997; Tinsley et al. 1998).

\subsection{Electrical stimulation induces calcium-dependent up-regulation of neuregulin-1 $\beta$ in dystrophic skeletal muscle cell lines}

Neuregulin (NRG) is one of many factors that increase utrophin expression (Miura and Jasmin 2006). It belongs to a family of proteins structurally related to the epidermal growth factor (EGF) that are synthesized in and secreted from motoneurons and muscle (Falls 2003). Four members of NRG proteins, NRG-1 to NRG-4, have been identified. The best-studied and most characterized products are those encoded by NRG-1 gene.

Neuregulin-1 (NRG-1) was initially described as a neurotrophic factor involved in neuromuscular junction formation in skeletal muscle, but recently it has emerged as a myokine, with relevant effects on myogenesis, muscle metabolism and regeneration, and has been considered as a strong candidate to transduce muscle adaptation to chronic exercise (Lebrasseur et al. 2003; Guma et al. 2010).

Interestingly, NRG-1 treatment increases utrophin mRNA levels and transcriptional activity in mouse and human myotubes (Gramolini et al. 1999; Khurana et al. 1999). Moreover, Krag et al. (2004) described that intraperitoneal injection of a small peptide region of NRG-1 ectodomain increases utrophin expression in $m d x$ mice (Krag et al. 2004). Observed increase was accompanied by a reduction in muscle degeneration and inflammation, and by decreased susceptibility to the damage induced by lengthening contractions. Improvement in muscle function was deemed to result specifically from the up-regulation of utrophin because NRG-1 administration has no beneficial effect in dystrophin/utrophin doubleknockout animals (Krag et al. 2004).

However, regardless the evidences supporting such important roles for NRG-1 in skeletal muscle, the molecular mechanisms involved in its expression are still unclear.

When we investigated the effect of membrane depolarization on global gene expression in dystrophic RCDMD cells using microarrays technology, our data revealed that membrane potential changes, induced by electrical stimulation, resulted in significant up or down regulation of 150 genes after $4 \mathrm{~h}$. Interestingly, two NRG-1 isoforms ( $\beta$ and $\gamma$ ) appear within the ten highest up-regulated genes (Cárdenas et al. 2010).

Taking into account the important biological effects of NRG-1 in the muscle and its potential clinical implication in DMD, we focused our study on the regulation of muscle NRG-1 expression, specifically on NRG-1 $\beta$ isoform, that displays a higher affinity for NRG receptor (Juretić et al. n.d.). NRG-1 $\beta$ increased expression was confirmed by quantitative PCR. We observed that electrical stimulation induces a significant increase of NRG-1 $\beta$ mRNA level in RCDMD cells, with a maximun at $4 \mathrm{~h}$ post-stimuli, but has no effect on NRG-1 $\beta$ expression in $\mathrm{RCMH}$ cells treated with the same procedure, suggesting that activation of molecular pathways involved in the regulation of NRG-1 $\beta$ gene expression are different in normal and dystrophic cells. Western blot analysis of stimulated RCDMD cells demonstrates that 
observed increase in NRG-1 $\beta$ mRNA levels was followed by actual enhancement of the corresponding protein (Juretić et al. n.d.).

Accumulating evidence suggests that integral dystrophin-DAPs complex components are also implicated in signaling in DMD, and that mutations in non-DAP protein encoding genes may lead to the muscular dystrophy phenotype, supporting the idea that more than one molecular pathway is implicated in the disease (Haslett et al. 2002). Thus, it is likely that the lack of DAP proteins in the cell membrane will somehow affect the regulation of $\mathrm{Ca}^{2+}$ transients and gene expression in dystrophic cells after electrical stimulation. In fact, Balghi et al. (2006) have demonstrated that $\mathrm{IP}_{3}$ production after depolarization is significantly elevated in SolC1(-) dystrophin deficient myotubes and that the presence of mini-dystrophin under the membrane leads to reduced $\mathrm{IP}_{3}$ production (Balghi et al. 2006b).

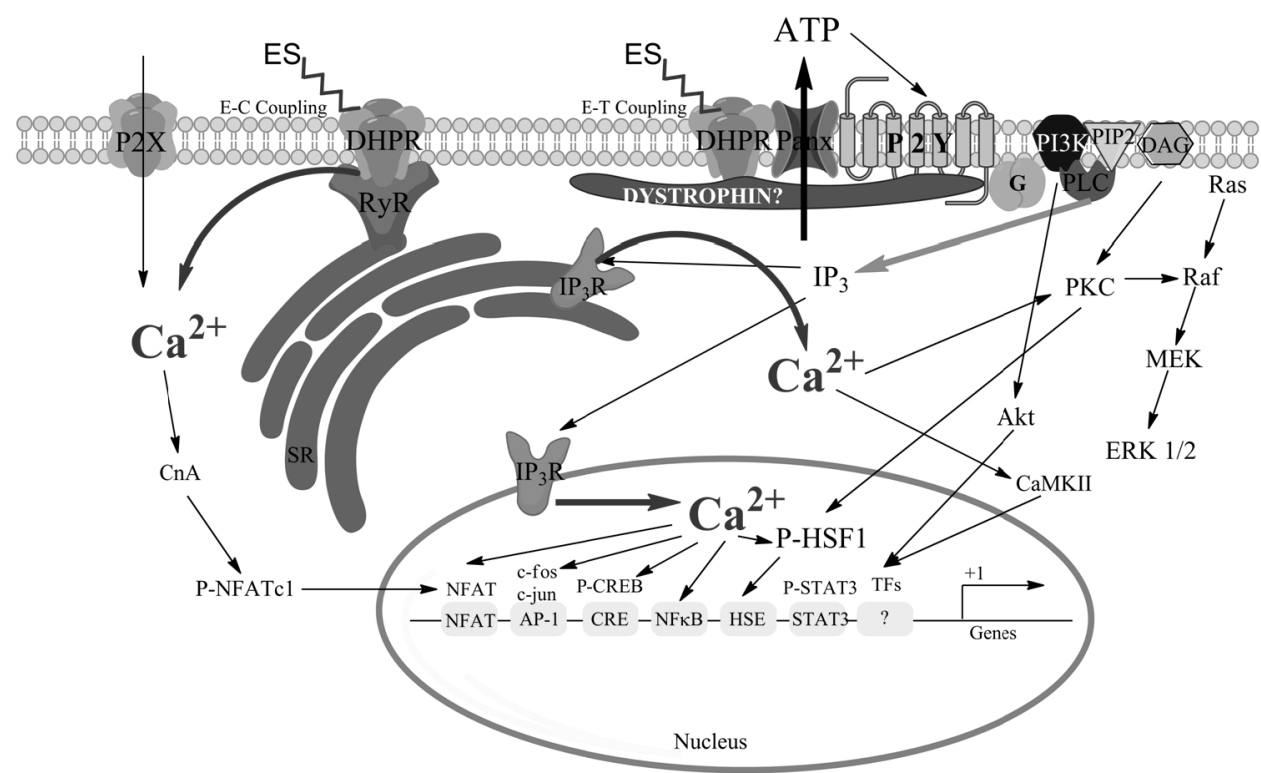

Fig. 1. Diagram for the model for excitation-transcription coupling in skeletal muscle.

Two protein complexes are proposed to be present in the transverse tubule (T-T) membrane. The first one is the excitation-contraction (E-C) complex, comprising the voltage sensing dihydropyridine receptor (DHPR, Cav1.1) and the ryanodine receptor (RyR). We propose that purinergic $\mathrm{P} 2 \mathrm{X}$ receptors also contribute to the fast calcium transient associated to E-C coupling. The excitation-transcription (E-T) coupling complex comprises also the DHPR, pannexin1 (Panx), the purinergic receptor P2Y linked to a G protein and possibly the phosphatidyl inositol 3 kinase (PI3K) and phospholipase C (PLC). It is likely that dystrophin is playing a role stabilizing this complex in the membrane. Upon electrical stimulation (ES), membrane depolarization will trigger a conformational change in DHPR which somehow will induce opening of Panx channel and ATP will be released. ATP acting on P2Y receptors will activate PI3K via G protein and in turn PLC will be recruited to the membrane producing inositol $(1,4,5)$ trisphosphate $\left(\mathrm{IP}_{3}\right)$ and diacyl glycerol $(\mathrm{DAG}) . \mathrm{IP}_{3} \mathrm{R}$ - mediated calcium signals will be responsible for activation of kinases (PKC, CaMK II, ERK $1 \frac{12}{2}$ ) and transcription factors leading finally to gene expression. 


\section{Final remarks}

Results discussed here point out to the important role of slow $\mathrm{Ca}^{2+}$ transients evoked by electrical stimulation in the activation of the pathways that couple excitation to gene expression in dystrophin-deficient muscle cells (a putative role for dystrophin is schematized in Fig. 1). If we find ways to intervene such pathways in a manner that can compensate dystrophin dysfunction, the understanding of this new role of dystrophin will give new insights to the design of a therapeutic strategy in order to potentiate muscle survival and regeneration in DMD.

\section{Acknowledgements}

We thank Sonja Buvinic, Mariana Casas and Nora Riveros, whose work and ideas provided input to this chapter. This work was supported by FONDECYT 1110467, 11100267, FONDAP 15010006, and CONICYT AT-24100066 (FA) and AT-24110211 (DV).

\section{References}

Abbracchio, MP, Boeynaems, JM, Barnard, EA, Boyer, JL, Kennedy, C, Miras-Portugal, MT, King, BF, Gachet, C, Jacobson, KA, Weisman, GA \& Burnstock, G (2003). Characterization of the UDP-glucose receptor (re-named here the P2Y14 receptor) adds diversity to the P2Y receptor family. Trends Pharmacol Sci, 24, 2, pp. 52-55.

Abbracchio, MP, Burnstock, G, Boeynaems, JM, Barnard, EA, Boyer, JL, Kennedy, C, Knight, GE, Fumagalli, M, Gachet, C, Jacobson, KA \& Weisman, GA (2006). International Union of Pharmacology LVIII: update on the P2Y G protein-coupled nucleotide receptors: from molecular mechanisms and pathophysiology to therapy. Pharmacol Rev, 58, 3, pp. 281-341.

Acharyya, S, Villalta, SA, Bakkar, N, Bupha-Intr, T, Janssen, PM, Carathers, M, Li, ZW, Beg, AA, Ghosh, S, Sahenk, Z, Weinstein, M, Gardner, KL, Rafael-Fortney, JA, Karin, M, Tidball, JG, Baldwin, AS \& Guttridge, DC (2007). Interplay of IKK/NF-kappaB signaling in macrophages and myofibers promotes muscle degeneration in Duchenne muscular dystrophy. J Clin Invest, 117, 4, pp. 889-901.

Ahn, AH \& Kunkel, LM (1993). The structural and functional diversity of dystrophin. Nat Genet, 3, 4, pp. 283-291.

Alderton, JM \& Steinhardt, RA (2000). How calcium influx through calcium leak channels is responsible for the elevated levels of calcium-dependent proteolysis in dystrophic myotubes. Trends Cardiovasc Med, 10, 6, pp. 268-272.

Allen, DG, Gervasio, OL, Yeung, EW \& Whitehead, NP (2010). Calcium and the damage pathways in muscular dystrophy. Can J Physiol Pharmacol, 88, 2, pp. 83-91.

Araya, R, Liberona, JL, Cardenas, JC, Riveros, N, Estrada, M, Powell, JA, Carrasco, MA \& Jaimovich, E (2003). Dihydropyridine receptors as voltage sensors for a depolarization-evoked, IP3R-mediated, slow calcium signal in skeletal muscle cells. J Gen Physiol, 121, 1, pp. 3-16.

Araya, R, Riquelme, MA, Brandan, E \& Saez, JC (2004). The formation of skeletal muscle myotubes requires functional membrane receptors activated by extracellular ATP. Brain Res Brain Res Rev, 47, 1-3, pp. 174-188. 
Baban, D \& Davies, KE (2008). Microarray analysis of mdx mice expressing high levels of utrophin: therapeutic implications for dystrophin deficiency. Neuromuscul Disord, 18, 3, pp. 239-247.

Balghi, H, Sebille, S, Constantin, B, Patri, S, Thoreau, V, Mondin, L, Mok, E, Kitzis, A, Raymond, G \& Cognard, C (2006a). Mini-dystrophin expression down-regulates overactivation of G protein-mediated IP3 signaling pathway in dystrophindeficient muscle cells. J Gen Physiol, 127, 2, pp. 171-182.

Balghi, H, Sebille, S, Mondin, L, Cantereau, A, Constantin, B, Raymond, G \& Cognard, C (2006b). Mini-dystrophin expression down-regulates IP3-mediated calcium release events in resting dystrophin-deficient muscle cells. J Gen Physiol, 128, 2, pp. 219-230.

Banachewicz, W, Suplat, D, Krzeminski, P, Pomorski, P \& Baranska, J (2005). P2 nucleotide receptors on C2C12 satellite cells. Purinergic Signal, 1, 3, pp. 249-257.

Baranova, A, Ivanov, D, Petrash, N, Pestova, A, Skoblov, M, Kelmanson, I, Shagin, D, Nazarenko, S, Geraymovych, E, Litvin, O, Tiunova, A, Born, TL, Usman, N, Staroverov, D, Lukyanov, S \& Panchin, Y (2004). The mammalian pannexin family is homologous to the invertebrate innexin gap junction proteins. Genomics, 83, 4, pp. 706-716.

Barbe, MT, Monyer, H \& Bruzzone, R (2006). Cell-cell communication beyond connexins: the pannexin channels. Physiology (Bethesda), 21, pp. 103-114.

Batchelor, CL \& Winder, SJ (2006). Sparks, signals and shock absorbers: how dystrophin loss causes muscular dystrophy. Trends Cell Biol, 16, 4, pp. 198-205.

Berchtold, MW, Brinkmeier, H \& Muntener, M (2000). Calcium ion in skeletal muscle: its crucial role for muscle function, plasticity, and disease. Physiol Rev, 80, 3, pp. 12151265.

Betto, R, Senter, L, Ceoldo, S, Tarricone, E, Biral, D \& Salviati, G (1999). Ecto-ATPase activity of alpha-sarcoglycan (adhalin). J Biol Chem, 274, 12, pp. 7907-7912.

Blake, DJ, Weir, A, Newey, SE \& Davies, KE (2002). Function and genetics of dystrophin and dystrophin-related proteins in muscle. Physiol Rev, 82, 2, pp. 291-329.

Boittin, FX, Petermann, O, Hirn, C, Mittaud, P, Dorchies, OM, Roulet, E \& Ruegg, UT (2006). Ca2+-independent phospholipase A2 enhances store-operated $\mathrm{Ca} 2+$ entry in dystrophic skeletal muscle fibers. J Cell Sci, 119, Pt 18, pp. 3733-3742.

Bours, MJ, Swennen, EL, Di Virgilio, F, Cronstein, BN \& Dagnelie, PC (2006). Adenosine 5'triphosphate and adenosine as endogenous signaling molecules in immunity and inflammation. Pharmacol Ther, 112, 2, pp. 358-404.

Broch-Lips, M, Pedersen, TH \& Nielsen, OB (2010). Effect of purinergic receptor activation on $\mathrm{Na}+-\mathrm{K}+$ pump activity, excitability, and function in depolarized skeletal muscle. Am J Physiol Cell Physiol, 298, 6, pp. C1438-1444.

Brunschweiger, A \& Muller, CE (2006). P2 receptors activated by uracil nucleotides--an update. Curr Med Chem, 13, 3, pp. 289-312.

Burnstock, G (2004). Introduction: P2 receptors. Curr Top Med Chem, 4, 8, pp. 793-803.

Burnstock, G \& Ulrich, H (2011). Purinergic signaling in embryonic and stem cell development. Cell Mol Life Sci, 68, 8, pp. 1369-1394.

Buvinic, S, Almarza, G, Bustamante, M, Casas, M, Lopez, J, Riquelme, M, Saez, JC, Huidobro-Toro, JP \& Jaimovich, E (2009). ATP released by electrical stimuli elicits 
calcium transients and gene expression in skeletal muscle. J Biol Chem, 284, 50, pp. 34490-34505.

Campbell, L, Abulrob, AN, Kandalaft, LE, Plummer, S, Hollins, AJ, Gibbs, A \& Gumbleton, M (2003). Constitutive expression of p-glycoprotein in normal lung alveolar epithelium and functionality in primary alveolar epithelial cultures. J Pharmacol Exp Ther, 304, 1, pp. 441-452.

Canto, C, Chibalin, AV, Barnes, BR, Glund, S, Suarez, E, Ryder, JW, Palacin, M, Zierath, JR, Zorzano, A \& Guma, A (2006). Neuregulins mediate calcium-induced glucose transport during muscle contraction. J Biol Chem, 281, 31, pp. 21690-21697.

Capote, J, DiFranco, M \& Vergara, JL (2010). Excitation-contraction coupling alterations in mdx and utrophin/dystrophin double knockout mice: a comparative study. Am J Physiol Cell Physiol, 298, 5, pp. C1077-1086.

Cárdenas, C, Juretic, N, Bevilacqua, J, García, N, Figueroa, R, Hartley, R, Taratuto, AL, Gejman, L, Riveros, N, Molgó, J \& Jaimovich, E (2010). Abnormal distribution of inositol 1,4,5-trisphosphate receptors in human muscle can be related to altered calcium signals and gene expression in Duchenne dystrophy derived cells. FASEB J. 24, 9, pp. 3210-3221

Cardenas, C, Liberona, JL, Molgo, J, Colasante, C, Mignery, GA \& Jaimovich, E (2005). Nuclear inositol 1,4,5-trisphosphate receptors regulate local $\mathrm{Ca}+$ transients and modulate cAMP response element binding protein phosphorylation. J Cell Sci, 118, Pt 14, pp. 3131-3140.

Carrasco, MA, Riveros, N, Rios, J, Muller, M, Torres, F, Pineda, J, Lantadilla, S \& Jaimovich, E (2003). Depolarization-induced slow calcium transients activate early genes in skeletal muscle cells. Am J Physiol Cell Physiol, 284, 6, pp. C1438-1447.

Casas, M, Figueroa, R, Jorquera, G, Escobar, M, Molgo, J \& Jaimovich, E (2010). IP(3)dependent, post-tetanic calcium transients induced by electrostimulation of adult skeletal muscle fibers. J Gen Physiol, 136, 4, pp. 455-467.

Chen, YW, Zhao, P, Borup, R \& Hoffman, EP (2000). Expression profiling in the muscular dystrophies: identification of novel aspects of molecular pathophysiology. J Cell Biol, 151, 6, pp. 1321-1336.

Cho, YR, Jang, HS, Kim, W, Park, SY \& Sohn, UD (2010). P2X and P2Y Receptors Mediate Contraction Induced by Electrical Field Stimulation in Feline Esophageal Smooth Muscle. Korean J Physiol Pharmacol, 14, 5, pp. 311-316.

Corriden, R \& Insel, PA (2010). Basal release of ATP: an autocrine-paracrine mechanism for cell regulation. Sci Signal, 3, 104, pp. re1.

Culligan, K, Banville, N, Dowling, P \& Ohlendieck, K (2002). Drastic reduction of calsequestrin-like proteins and impaired calcium binding in dystrophic $\mathrm{mdx}$ muscle. J Appl Physiol, 92, 2, pp. 435-445.

Cunha, RA \& Sebastiao, AM (1993). Adenosine and adenine nucleotides are independently released from both the nerve terminals and the muscle fibres upon electrical stimulation of the innervated skeletal muscle of the frog. Pflugers Arch, 424, 5-6, pp. 503-510.

D'Hondt, C, Ponsaerts, R, De Smedt, H, Vinken, M, De Vuyst, E, De Bock, M, Wang, N, Rogiers, V, Leybaert, L, Himpens, B \& Bultynck, G (2011). Pannexin channels in 
ATP release and beyond: an unexpected rendezvous at the endoplasmic reticulum. Cell Signal, 23, 2, pp. 305-316.

Deconinck, N, Tinsley, J, De Backer, F, Fisher, R, Kahn, D, Phelps, S, Davies, K \& Gillis, JM (1997). Expression of truncated utrophin leads to major functional improvements in dystrophin-deficient muscles of mice. Nat Med, 3, 11, pp. 1216-1221.

Dennis, CL, Tinsley, JM, Deconinck, AE \& Davies, KE (1996). Molecular and functional analysis of the utrophin promoter. Nucleic Acids Res, 24, 9, pp. 1646-1652.

Divet, A, Lompre, AM \& Huchet-Cadiou, C (2005). Effect of cyclopiazonic acid, an inhibitor of the sarcoplasmic reticulum Ca-ATPase, on skeletal muscles from normal and mdx mice. Acta Physiol Scand, 184, 3, pp. 173-186.

Dogra, C, Srivastava, DS \& Kumar, A (2008). Protein-DNA array-based identification of transcription factor activities differentially regulated in skeletal muscle of normal and dystrophin-deficient mdx mice. Mol Cell Biochem, 312, 1-2, pp. 17-24.

Dominov, JA \& Miller, JB (1996). POU homeodomain genes and myogenesis. Dev Genet, 19, 2, pp. 108-118.

Dubyak, GR (2009). Both sides now: multiple interactions of ATP with pannexin-1 hemichannels. Focus on "A permeant regulating its permeation pore: inhibition of pannexin 1 channels by ATP". Am J Physiol Cell Physiol, 296, 2, pp. C235-241.

Edwards, JN, Friedrich, O, Cully, TR, von Wegner, F, Murphy, RM \& Launikonis, BS (2010). Upregulation of store-operated Ca2+ entry in dystrophic mdx mouse muscle. Am J Physiol Cell Physiol, 299, 1, pp. C42-50.

Eltit, JM, Garcia, AA, Hidalgo, J, Liberona, JL, Chiong, M, Lavandero, S, Maldonado, E \& Jaimovich, E (2006). Membrane electrical activity elicits inositol 1,4,5-trisphosphatedependent slow $\mathrm{Ca} 2+$ signals through a Gbetagamma/phosphatidylinositol 3kinase gamma pathway in skeletal myotubes. J Biol Chem, 281, 17, pp. 12143-12154.

Eltit, JM, Yang, T, Li, H, Molinski, TF, Pessah, IN, Allen, PD \& Lopez, JR (2010). RyR1mediated $\mathrm{Ca} 2+$ leak and $\mathrm{Ca} 2+$ entry determine resting intracellular $\mathrm{Ca} 2+$ in skeletal myotubes. J Biol Chem, 285, 18, pp. 13781-13787.

Estrada, M, Cardenas, C, Liberona, JL, Carrasco, MA, Mignery, GA, Allen, PD \& Jaimovich, E (2001). Calcium transients in 1B5 myotubes lacking ryanodine receptors are related to inositol trisphosphate receptors. J Biol Chem, 276, 25, pp. 22868-22874.

Evans, NP, Misyak, SA, Robertson, JL, Bassaganya-Riera, J \& Grange, RW (2009a). Dysregulated intracellular signaling and inflammatory gene expression during initial disease onset in Duchenne muscular dystrophy. Am J Phys Med Rehabil, 88, 6, pp. 502-522.

Evans, NP, Misyak, SA, Robertson, JL, Bassaganya-Riera, J \& Grange, RW (2009b). Immunemediated mechanisms potentially regulate the disease time-course of duchenne muscular dystrophy and provide targets for therapeutic intervention. $P M R, 1,8$, pp. 755-768.

Falls, DL (2003). Neuregulins: functions, forms, and signaling strategies. Exp Cell Res, 284, 1, pp. 14-30.

Fitz, JG (2007). Regulation of cellular ATP release. Trans Am Clin Climatol Assoc, 118, pp. 199208. 
Gervasio, OL, Whitehead, NP, Yeung, EW, Phillips, WD \& Allen, DG (2008). TRPC1 binds to caveolin-3 and is regulated by Src kinase - role in Duchenne muscular dystrophy. $J$ Cell Sci, 121, Pt 13, pp. 2246-2255.

Goll, DE, Thompson, VF, Li, H, Wei, W \& Cong, J (2003). The calpain system. Physiol Rev, 83, 3, pp. 731-801.

Goonasekera, SA, Lam, CK, Millay, DP, Sargent, MA, Hajjar, RJ, Kranias, EG \& Molkentin, JD (2011). Mitigation of muscular dystrophy in mice by SERCA overexpression in skeletal muscle. J Clin Invest, 121, 3, pp. 1044-1052.

Gramolini, AO, Angus, LM, Schaeffer, L, Burton, EA, Tinsley, JM, Davies, KE, Changeux, JP \& Jasmin, BJ (1999). Induction of utrophin gene expression by heregulin in skeletal muscle cells: role of the N-box motif and GA binding protein. Proc Natl Acad Sci U S A, 96, 6, pp. 3223-3227.

Grasa, L, Gil, V, Gallego, D, Martin, MT \& Jimenez, M (2009). P2Y(1) receptors mediate inhibitory neuromuscular transmission in the rat colon. Br J Pharmacol, 158, 6, pp. 1641-1652.

Grishin, SN, Teplov, AY, Galkin, AV, Devyataev, AM, Zefirov, AL, Mukhamedyarov, MA, Ziganshin, AU, Burnstock, G \& Palotas, A (2006). Different effects of ATP on the contractile activity of mice diaphragmatic and skeletal muscles. Neurochem Int, 49, 8, pp. 756-763.

Guma, A, Martinez-Redondo, V, Lopez-Soldado, I, Canto, C \& Zorzano, A (2010). Emerging role of neuregulin as a modulator of muscle metabolism. Am J Physiol Endocrinol Metab, 298, 4, pp. E742-750.

Hack, AA, Groh, ME \& McNally, EM (2000). Sarcoglycans in muscular dystrophy. Microsc Res Tech, 48, 3-4, pp. 167-180.

Haslett, JN, Sanoudou, D, Kho, AT, Bennett, RR, Greenberg, SA, Kohane, IS, Beggs, AH \& Kunkel, LM (2002). Gene expression comparison of biopsies from Duchenne muscular dystrophy (DMD) and normal skeletal muscle. Proc Natl Acad Sci U S A, 99, 23, pp. 15000-15005.

Hellsten, Y, Maclean, D, Radegran, G, Saltin, B \& Bangsbo, J (1998). Adenosine concentrations in the interstitium of resting and contracting human skeletal muscle. Circulation, 98, 1, pp. 6-8.

Hirata, M, Sakuma, K, Okajima, S, Fujiwara, H, Inashima, S, Yasuhara, M \& Kubo, T (2007). Increased expression of neuregulin-1 in differentiating muscle satellite cells and in motoneurons during muscle regeneration. Acta Neuropathol, 113, 4, pp. 451-459.

Hnia, K, Gayraud, J, Hugon, G, Ramonatxo, M, De La Porte, S, Matecki, S \& Mornet, D (2008). L-arginine decreases inflammation and modulates the nuclear factorkappaB/matrix metalloproteinase cascade in mdx muscle fibers. Am J Pathol, 172, 6, pp. 1509-1519.

Hollingworth, S, Zeiger, U \& Baylor, SM (2008). Comparison of the myoplasmic calcium transient elicited by an action potential in intact fibres of $\mathrm{mdx}$ and normal mice. $J$ Physiol, 586, Pt 21, pp. 5063-5075.

Iwata, Y, Katanosaka, Y, Hisamitsu, T \& Wakabayashi, S (2007). Enhanced $\mathrm{Na}+\mathrm{H}+$ exchange activity contributes to the pathogenesis of muscular dystrophy via involvement of P2 receptors. Am J Pathol, 171, 5, pp. 1576-1587. 
Jacobson, KA \& Boeynaems, JM (2010). P2Y nucleotide receptors: promise of therapeutic applications. Drug Discov Today, 15, 13-14, pp. 570-578.

Jacobson, KA, Ivanov, AA, de Castro, S, Harden, TK \& Ko, H (2009). Development of selective agonists and antagonists of P2Y receptors. Purinergic Signal, 5, 1, pp. 75-89.

Jaimovich, E, Reyes, R, Liberona, JL \& Powell, JA (2000). IP(3) receptors, IP(3) transients, and nucleus-associated $\mathrm{Ca}(2+)$ signals in cultured skeletal muscle. Am J Physiol Cell Physiol, 278, 5, pp. C998-C1010.

Jarvis, MF \& Khakh, BS (2009). ATP-gated P2X cation-channels. Neuropharmacology, 56, 1, pp. 208-215.

Jia, M, Li, MX, Fields, RD \& Nelson, PG (2007). Extracellular ATP in activity-dependent remodeling of the neuromuscular junction. Dev Neurobiol, 67, 7, pp. 924-932.

Jiang, T, Yeung, D, Lien, CF \& Gorecki, DC (2005). Localized expression of specific P2X receptors in dystrophin-deficient DMD and mdx muscle. Neuromuscul Disord, 15, 3 , pp. 225-236.

Jorquera, G, Juretic, N, Jaimovich, E \& Riveros, N (2009). Membrane depolarization induces calcium-dependent upregulation of Hsp70 and Hmox-1 in skeletal muscle cells. Am J Physiol Cell Physiol, 297, 3, pp. C581-590.

Juretić, N, Jorquera, G, Caviedes, P, Jaimovich, E \& Riveros, N (n.d.). Electrical stimulation induces calcium-dependent up-regulation of neuregulin- $1 \beta$ in dystrophic skeletal muscle cell lines. Manuscript in preparation

Juretic, N, Garcia-Huidobro, P, Iturrieta, JA, Jaimovich, E \& Riveros, N (2006). Depolarization-induced slow $\mathrm{Ca} 2+$ transients stimulate transcription of IL-6 gene in skeletal muscle cells. Am J Physiol Cell Physiol, 290, 5, pp. C1428-1436.

Juretic, N, Urzua, U, Munroe, DJ, Jaimovich, E \& Riveros, N (2007). Differential gene expression in skeletal muscle cells after membrane depolarization. J Cell Physiol, 210, 3, pp. 819-830.

Kapsa, R, Kornberg, AJ \& Byrne, E (2003). Novel therapies for Duchenne muscular dystrophy. Lancet Neurol, 2, 5, pp. 299-310.

Kargacin, ME \& Kargacin, GJ (1996). The sarcoplasmic reticulum calcium pump is functionally altered in dystrophic muscle. Biochim Biophys Acta, 1290, 1, pp. 4-8.

Khurana, TS, Hoffman, EP \& Kunkel, LM (1990). Identification of a chromosome 6-encoded dystrophin-related protein. J Biol Chem, 265, 28, pp. 16717-16720.

Khurana, TS, Rosmarin, AG, Shang, J, Krag, TO, Das, S \& Gammeltoft, S (1999). Activation of utrophin promoter by heregulin via the ets-related transcription factor complex GA-binding protein alpha/beta. Mol Biol Cell, 10, 6, pp. 2075-2086.

Krag, TO, Bogdanovich, S, Jensen, CJ, Fischer, MD, Hansen-Schwartz, J, Javazon, EH, Flake, AW, Edvinsson, L \& Khurana, TS (2004). Heregulin ameliorates the dystrophic phenotype in mdx mice. Proc Natl Acad Sci U S A, 101, 38, pp. 13856-13860.

Kumar, A \& Boriek, AM (2003). Mechanical stress activates the nuclear factor-kappaB pathway in skeletal muscle fibers: a possible role in Duchenne muscular dystrophy. FASEB J, 17, 3, pp. 386-396.

Lang, JM, Esser, KA \& Dupont-Versteegden, EE (2004). Altered activity of signaling pathways in diaphragm and tibialis anterior muscle of dystrophic mice. Exp Biol Med (Maywood), 229, 6, pp. 503-511. 
Lebrasseur, NK, Cote, GM, Miller, TA, Fielding, RA \& Sawyer, DB (2003). Regulation of neuregulin/ErbB signaling by contractile activity in skeletal muscle. Am J Physiol Cell Physiol, 284, 5, pp. C1149-1155.

Liberona, JL, Powell, JA, Shenoi, S, Petherbridge, L, Caviedes, R \& Jaimovich, E (1998). Differences in both inositol 1,4,5-trisphosphate mass and inositol 1,4,5trisphosphate receptors between normal and dystrophic skeletal muscle cell lines. Muscle Nerve, 21, 7, pp. 902-909.

Liu, HT, Toychiev, AH, Takahashi, N, Sabirov, RZ \& Okada, Y (2008). Maxi-anion channel as a candidate pathway for osmosensitive ATP release from mouse astrocytes in primary culture. Cell Res, 18, 5, pp. 558-565.

Lopez, JR, Briceno, LE, Sanchez, V \& Horvart, D (1987). Myoplasmic (Ca2+) in Duchenne muscular dystrophy patients. Acta Cient Venez, 38, 4, pp. 503-504.

Love, DR, Hill, DF, Dickson, G, Spurr, NK, Byth, BC, Marsden, RF, Walsh, FS, Edwards, YH \& Davies, KE (1989). An autosomal transcript in skeletal muscle with homology to dystrophin. Nature, 339, 6219, pp. 55-58.

Matsumura, K, Ervasti, JM, Ohlendieck, K, Kahl, SD \& Campbell, KP (1992). Association of dystrophin-related protein with dystrophin-associated proteins in $\mathrm{mdx}$ mouse muscle. Nature, 360, 6404, pp. 588-591.

May, C, Weigl, L, Karel, A \& Hohenegger, M (2006). Extracellular ATP activates ERK1/ERK2 via a metabotropic P2Y1 receptor in a Ca2+ independent manner in differentiated human skeletal muscle cells. Biochem Pharmacol, 71, 10, pp. 1497-1509.

Messina, S, Bitto, A, Aguennouz, M, Vita, GL, Polito, F, Irrera, N, Altavilla, D, Marini, H, Migliorato, A, Squadrito, F \& Vita, G (2011). The soy isoflavone genistein blunts nuclear factor kappa-B, MAPKs and TNF-alpha activation and ameliorates muscle function and morphology in mdx mice. Neuromuscul Disord, 21, 8, pp. 579-589.

Millay, DP, Sargent, MA, Osinska, H, Baines, CP, Barton, ER, Vuagniaux, G, Sweeney, HL, Robbins, J \& Molkentin, JD (2008). Genetic and pharmacologic inhibition of mitochondrial-dependent necrosis attenuates muscular dystrophy. Nat Med, 14, 4, pp. 442-447.

Miura, P \& Jasmin, BJ (2006). Utrophin upregulation for treating Duchenne or Becker muscular dystrophy: how close are we? Trends Mol Med, 12, 3, pp. 122-129.

Mokri, B \& Engel, AG (1998). Duchenne dystrophy: electron microscopic findings pointing to a basic or early abnormality in the plasma membrane of the muscle fiber. 1975. Neurology, 51, 1, pp. 1 and 10 pages following.

Morine, KJ, Sleeper, MM, Barton, ER \& Sweeney, HL (2010). Overexpression of SERCA1a in the $\mathrm{mdx}$ diaphragm reduces susceptibility to contraction-induced damage. Hum Gene Ther, 21, 12, pp. 1735-1739.

Nakamura, T, Iwanaga, K, Murata, T, Hori, M \& Ozaki, H (2011). ATP induces contraction mediated by the P2Y(2) receptor in rat intestinal subepithelial myofibroblasts. Eur J Pharmacol, 657, 1-3, pp. 152-158.

Nakata, H, Yoshioka, K \& Kamiya, T (2004). Purinergic-receptor oligomerization: implications for neural functions in the central nervous system. Neurotox Res, 6, 4, pp. 291-297. 
Nguyen, TM, Ellis, JM, Love, DR, Davies, KE, Gatter, KC, Dickson, G \& Morris, GE (1991). Localization of the DMDL gene-encoded dystrophin-related protein using a panel of nineteen monoclonal antibodies: presence at neuromuscular junctions, in the sarcolemma of dystrophic skeletal muscle, in vascular and other smooth muscles, and in proliferating brain cell lines. J Cell Biol, 115, 6, pp. 1695-1700.

Niebroj-Dobosz, I \& Hausmanowa-Petrusewicz, I (2005). The involvement of oxidative stress in determining the severity and progress of pathological processes in dystrophin-deficient muscles. Acta Biochim Pol, 52, 2, pp. 449-452.

Noguchi, S, Tsukahara, T, Fujita, M, Kurokawa, R, Tachikawa, M, Toda, T, Tsujimoto, A, Arahata, K \& Nishino, I (2003). cDNA microarray analysis of individual Duchenne muscular dystrophy patients. Hum Mol Genet, 12, 6, pp. 595-600.

North, RA (2002). Molecular physiology of P2X receptors. Physiol Rev, 82, 4, pp. 1013-1067.

Ohlendieck, K, Ervasti, JM, Matsumura, K, Kahl, SD, Leveille, CJ \& Campbell, KP (1991). Dystrophin-related protein is localized to neuromuscular junctions of adult skeletal muscle. Neuron, 7, 3, pp. 499-508.

Petrof, BJ, Shrager, JB, Stedman, HH, Kelly, AM \& Sweeney, HL (1993). Dystrophin protects the sarcolemma from stresses developed during muscle contraction. Proc Natl Acad Sci U S A, 90, 8, pp. 3710-3714.

Porreca, E, Guglielmi, MD, Uncini, A, Di Gregorio, P, Angelini, A, Di Febbo, C, Pierdomenico, SD, Baccante, G \& Cuccurullo, F (1999). Haemostatic abnormalities, cardiac involvement and serum tumor necrosis factor levels in X-linked dystrophic patients. Thromb Haemost, 81, 4, pp. 543-546.

Porter, JD, Guo, W, Merriam, AP, Khanna, S, Cheng, G, Zhou, X, Andrade, FH, Richmonds, C \& Kaminski, HJ (2003a). Persistent over-expression of specific CC class chemokines correlates with macrophage and T-cell recruitment in mdx skeletal muscle. Neuromuscul Disord, 13, 3, pp. 223-235.

Porter, JD, Khanna, S, Kaminski, HJ, Rao, JS, Merriam, AP, Richmonds, CR, Leahy, P, Li, J, Guo, W \& Andrade, FH (2002). A chronic inflammatory response dominates the skeletal muscle molecular signature in dystrophin-deficient mdx mice. Hum Mol Genet, 11, 3, pp. 263-272.

Porter, JD, Merriam, AP, Leahy, P, Gong, B, Feuerman, J, Cheng, G \& Khanna, S (2004). Temporal gene expression profiling of dystrophin-deficient ( $\mathrm{mdx}$ ) mouse diaphragm identifies conserved and muscle group-specific mechanisms in the pathogenesis of muscular dystrophy. Hum Mol Genet, 13, 3, pp. 257-269.

Porter, JD, Merriam, AP, Leahy, P, Gong, B \& Khanna, S (2003b). Dissection of temporal gene expression signatures of affected and spared muscle groups in dystrophindeficient (mdx) mice. Hum Mol Genet, 12, 15, pp. 1813-1821.

Powell, JA, Carrasco, MA, Adams, DS, Drouet, B, Rios, J, Muller, M, Estrada, M \& Jaimovich, E (2001). IP(3) receptor function and localization in myotubes: an unexplored $\mathrm{Ca}(2+)$ signaling pathway in skeletal muscle. J Cell Sci, 114, Pt 20, pp. 3673-3683.

Rando, TA (2001). The dystrophin-glycoprotein complex, cellular signaling, and the regulation of cell survival in the muscular dystrophies. Muscle Nerve, 24, 12, pp. 1575-1594. 
Raqeeb, A, Sheng, J, Ao, N \& Braun, AP (2011). Purinergic P2Y2 receptors mediate rapid $\mathrm{Ca}(2+)$ mobilization, membrane hyperpolarization and nitric oxide production in human vascular endothelial cells. Cell Calcium, 49, 4, pp. 240-248.

Roberds, SL, Leturcq, F, Allamand, V, Piccolo, F, Jeanpierre, M, Anderson, RD, Lim, LE, Lee, JC, Tome, FM, Romero, NB \& et al. (1994). Missense mutations in the adhalin gene linked to autosomal recessive muscular dystrophy. Cell, 78, 4, pp. 625-633.

Robert, V, Massimino, ML, Tosello, V, Marsault, R, Cantini, M, Sorrentino, V \& Pozzan, T (2001). Alteration in calcium handling at the subcellular level in mdx myotubes. $J$ Biol Chem, 276, 7, pp. 4647-4651.

Ryten, M, Dunn, PM, Neary, JT \& Burnstock, G (2002). ATP regulates the differentiation of mammalian skeletal muscle by activation of a P2X5 receptor on satellite cells. J Cell Biol, 158, 2, pp. 345-355.

Ryten, M, Yang, SY, Dunn, PM, Goldspink, G \& Burnstock, G (2004). Purinoceptor expression in regenerating skeletal muscle in the $\mathrm{mdx}$ mouse model of muscular dystrophy and in satellite cell cultures. FASEB J, 18, 12, pp. 1404-1406.

Sabirov, RZ \& Okada, Y (2005). ATP release via anion channels. Purinergic Signal, 1, 4, pp. 311-328.

Sandona, D, Danieli-Betto, D, Germinario, E, Biral, D, Martinello, T, Lioy, A, Tarricone, E, Gastaldello, S \& Betto, R (2005). The T-tubule membrane ATP-operated P2X4 receptor influences contractility of skeletal muscle. FASEB J, 19, 9, pp. 1184-1186.

Sandona, D, Gastaldello, S, Martinello, T \& Betto, R (2004). Characterization of the ATPhydrolysing activity of alpha-sarcoglycan. Biochem J, 381, Pt 1, pp. 105-112.

Shestopalov, VI \& Panchin, Y (2008). Pannexins and gap junction protein diversity. Cell Mol Life Sci, 65, 3, pp. 376-394.

Silinsky, EM \& Redman, RS (1996). Synchronous release of ATP and neurotransmitter within milliseconds of a motor nerve impulse in the frog. J Physiol, 492 ( Pt 3), pp. 815-822.

Smith, DO (1991). Sources of adenosine released during neuromuscular transmission in the rat. J Physiol, 432, pp. 343-354.

Spencer, MJ, Croall, DE \& Tidball, JG (1995). Calpains are activated in necrotic fibers from mdx dystrophic mice. J Biol Chem, 270, 18, pp. 10909-10914.

Suadicani, SO, Brosnan, CF \& Scemes, E (2006). P2X7 receptors mediate ATP release and amplification of astrocytic intercellular Ca2+ signaling. J Neurosci, 26, 5, pp. 13781385.

Surprenant, A \& North, RA (2009). Signaling at purinergic P2X receptors. Annu Rev Physiol, 71, pp. 333-359.

Tinsley, J, Deconinck, N, Fisher, R, Kahn, D, Phelps, S, Gillis, JM \& Davies, K (1998). Expression of full-length utrophin prevents muscular dystrophy in mdx mice. Nat Med, 4, 12, pp. 1441-1444.

Tinsley, JM, Blake, DJ, Roche, A, Fairbrother, U, Riss, J, Byth, BC, Knight, AE, KendrickJones, J, Suthers, GK, Love, DR \& et al. (1992). Primary structure of dystrophinrelated protein. Nature, 360, 6404, pp. 591-593. 
Tinsley, JM, Potter, AC, Phelps, SR, Fisher, R, Trickett, JI \& Davies, KE (1996). Amelioration of the dystrophic phenotype of mdx mice using a truncated utrophin transgene. Nature, 384, 6607, pp. 349-353.

Turk, R, Sterrenburg, E, de Meijer, EJ, van Ommen, GJ, den Dunnen, JT \& t Hoen, PA (2005). Muscle regeneration in dystrophin-deficient $\mathrm{mdx}$ mice studied by gene expression profiling. BMC Genomics, 6, pp. 98.

Turner, PR, Fong, PY, Denetclaw, WF \& Steinhardt, RA (1991). Increased calcium influx in dystrophic muscle. J Cell Biol, 115, 6, pp. 1701-1712.

Turner, PR, Schultz, R, Ganguly, B \& Steinhardt, RA (1993). Proteolysis results in altered leak channel kinetics and elevated free calcium in mdx muscle. J Membr Biol, 133, 3, pp. 243-251.

Turner, PR, Westwood, T, Regen, CM \& Steinhardt, RA (1988). Increased protein degradation results from elevated free calcium levels found in muscle from $\mathrm{mdx}$ mice. Nature, 335, 6192, pp. 735-738.

Vandebrouck, A, Ducret, T, Basset, O, Sebille, S, Raymond, G, Ruegg, U, Gailly, P, Cognard, C \& Constantin, B (2006). Regulation of store-operated calcium entries and mitochondrial uptake by minidystrophin expression in cultured myotubes. FASEB J, 20, 1, pp. 136-138.

Vandebrouck, C, Martin, D, Colson-Van Schoor, M, Debaix, H \& Gailly, P (2002). Involvement of TRPC in the abnormal calcium influx observed in dystrophic (mdx) mouse skeletal muscle fibers. J Cell Biol, 158, 6, pp. 1089-1096.

Volonte, C \& D'Ambrosi, N (2009). Membrane compartments and purinergic signalling: the purinome, a complex interplay among ligands, degrading enzymes, receptors and transporters. FEBS J, 276, 2, pp. 318-329.

von Kugelgen, I (2006). Pharmacological profiles of cloned mammalian P2Y-receptor subtypes. Pharmacol Ther, 110, 3, pp. 415-432.

Voss, AA (2009). Extracellular ATP inhibits chloride channels in mature mammalian skeletal muscle by activating P2Y1 receptors. J Physiol, 587, Pt 23, pp. 5739-5752.

Winder, SJ, Hemmings, L, Maciver, SK, Bolton, SJ, Tinsley, JM, Davies, KE, Critchley, DR \& Kendrick-Jones, J (1995). Utrophin actin binding domain: analysis of actin binding and cellular targeting. J Cell Sci, 108 ( Pt 1), pp. 63-71.

Woods, CE, Novo, D, DiFranco, M \& Vergara, JL (2004). The action potential-evoked sarcoplasmic reticulum calcium release is impaired in $\mathrm{mdx}$ mouse muscle fibres. $J$ Physiol, 557, Pt 1, pp. 59-75.

Yegutkin, GG (2008). Nucleotide- and nucleoside-converting ectoenzymes: Important modulators of purinergic signalling cascade. Biochim Biophys Acta, 1783, 5, pp. 673694.

Yeung, D, Kharidia, R, Brown, SC \& Gorecki, DC (2004). Enhanced expression of the P2X4 receptor in Duchenne muscular dystrophy correlates with macrophage invasion. Neurobiol Dis, 15, 2, pp. 212-220.

Yeung, D, Zablocki, K, Lien, CF, Jiang, T, Arkle, S, Brutkowski, W, Brown, J, Lochmuller, H, Simon, J, Barnard, EA \& Gorecki, DC (2006). Increased susceptibility to ATP via alteration of P2X receptor function in dystrophic mdx mouse muscle cells. FASEB J, 20, 6, pp. 610-620. 
Yeung, EW, Whitehead, NP, Suchyna, TM, Gottlieb, PA, Sachs, F \& Allen, DG (2005). Effects of stretch-activated channel blockers on [Ca2+]i and muscle damage in the $\mathrm{mdx}$ mouse. J Physiol, 562, Pt 2, pp. 367-380.

Zhang, BT, Yeung, SS, Allen, DG, Qin, L \& Yeung, EW (2008). Role of the calcium-calpain pathway in cytoskeletal damage after eccentric contractions. J Appl Physiol, 105, 1, pp. 352-357. 


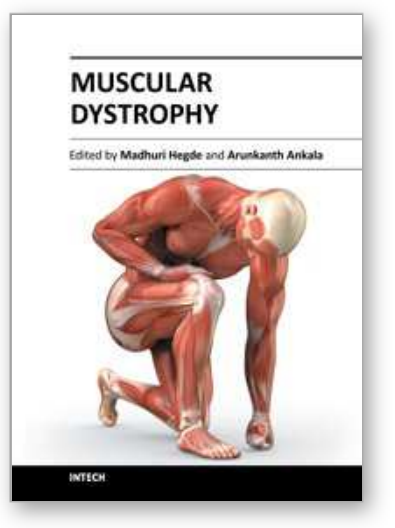

\author{
Muscular Dystrophy \\ Edited by Dr. Madhuri Hegde
}

ISBN 978-953-51-0603-6

Hard cover, 544 pages

Publisher InTech

Published online 09, May, 2012

Published in print edition May, 2012

With more than 30 different types and subtypes known and many more yet to be classified and characterized, muscular dystrophy is a highly heterogeneous group of inherited neuromuscular disorders. This book provides a comprehensive overview of the various types of muscular dystrophies, genes associated with each subtype, disease diagnosis, management as well as available treatment options. Though each different type and subtype of muscular dystrophy is associated with a different causative gene, the majority of them have overlapping clinical presentations, making molecular diagnosis inevitable for both disease diagnosis as well as patient management. This book discusses the currently available diagnostic approaches that have revolutionized clinical research. Pathophysiology of the different muscular dystrophies, multifaceted functions of the involved genes as well as efforts towards diagnosis and effective patient management, are also discussed. Adding value to the book are the included reports on ongoing studies that show a promise for future therapeutic strategies.

\title{
How to reference
}

In order to correctly reference this scholarly work, feel free to copy and paste the following:

Nevenka Juretić, Francisco Altamirano, Denisse Valladares and Enrique Jaimovich (2012). Altered Gene Expression Pathways in Duchenne Muscular Dystrophy, Muscular Dystrophy, Dr. Madhuri Hegde (Ed.), ISBN: 978-953-51-0603-6, InTech, Available from: http://www.intechopen.com/books/muscular-dystrophy/alteredgene-expression-pathways-in-duchenne-muscular-dystrophy

\section{INTECH}

open science | open minds

\section{InTech Europe}

University Campus STeP Ri

Slavka Krautzeka 83/A

51000 Rijeka, Croatia

Phone: +385 (51) 770447

Fax: +385 (51) 686166

www.intechopen.com

\section{InTech China}

Unit 405, Office Block, Hotel Equatorial Shanghai

No.65, Yan An Road (West), Shanghai, 200040, China

中国上海市延安西路65号上海国际贵都大饭店办公楼405单元

Phone: +86-21-62489820

Fax: $+86-21-62489821$ 
(C) 2012 The Author(s). Licensee IntechOpen. This is an open access article distributed under the terms of the Creative Commons Attribution 3.0 License, which permits unrestricted use, distribution, and reproduction in any medium, provided the original work is properly cited. 